Dialectologia 19 (2017), 41-66.

ISSN: 2013-2247

Received 11 March 2015.

Accepted 10 June 2015.

\title{
SIKH AND HINDU INDIAN THAI NAMING BY SEMANTIC DOMAINS
}

\author{
Warintorn BENJASRI \\ Mahidol University (Thailand)* \\ variinn@gmail.com
}

\begin{abstract}
This article will explore the traits of Sikh and Hindu Indian Thai naming by semantic domains. According to Nida (1975: 174), groups of meanings, such as names, which share a similar semantic component are known as semantic domains. Ottenheimer (2006: 19) saw a semantic domain as "a specific area of cultural emphasis". The results of this study will shed light on the different worldviews of Hindus and Sikhs. The results show the semantic domain of Hindu Indian Thais' naming is divided into 3 types; 1 ) entities, 2) abstract and 3) events in sequence. The semantic domains of Sikh Indian Thais naming is 1 ) abstract, 2) entities and 3) events in sequence.
\end{abstract}

\section{Keywords}

naming, semantic domains, ethnolinguistics, Indian Thai

\section{SIJ Y TAILANDÉS HINDÚ Y LA DESIGNACIÓN DE CAMPOS SEMÁNTICOS}

\section{Resumen}

Este artículo explorará los rasgos de Sij y tailandés hindú en la designación de campos semánticos. Según Nida (1975: 174), los grupos de significados, como los nombres, que comparten un componente semántico similar, se denominan campos semánticos. Ottenheimer (2006: 19) consideró un campo semántico como "una área específica de énfasis cultural". Los resultados de este estudio arrojarán luz sobre las diferentes visiones de mundo de hindúes y sijs y demuestrarán que el campo semántico de la

* 999 Phuttamonthon 4 Road, Salaya, Nakhon Pathom 73170, Thailand. 
denominación de los tailandeses hindúes se divide en 3 tipos; 1) entidades, 2) abstracciones y 3) eventos en secuencia. Los campos semánticos de la denominación tailandesa india sij son: 1) abstracciones, 2) entidades y 3 ) eventos en secuencia.

Palabras clave

denominación, campos semánticos, etnolingüística, tailandés hindú

\section{Introduction}

One of the most prominent and unique features of any and all societies is the names which its people bear. For it is in the names of the people that all of the roots and influences on that society and its culture are reflected. In Mphande's (2006) opinion, these special linguistic phenomena are not only self-significant but are also indicative of cultural and societal influences such as social status, legendary histories, and phonological processes. For all of these reasons, names are an important subject for linguistic study. According to James (1975), the study of these influences takes place within the field of Ethnosemantics, which by definition focuses on the behavior of ethnic groups and attempts to understand the semantic domains (categories) used by each. Ethnosemantics especially focuses on studying the vocabulary of a particular language given that the vocabulary will generally somewhat reflect the entire range of semantic ideas within that language's speakers.

The nation of India has been an important influence on Thailand, particularly with regard to the court system. Dhiravegin (2008) stated that, generally speaking, the Brahminism of the Indian subcontinent and its peoples has been one of the most powerful influencers on Thai beliefs and values. The Office of the Defence Attache, Royal Thai Embassy (2011) reports that currently there are approximately 150,000 Indian people living in Thailand; in addition to these, many have migrated to the nearby countries of Brunei, Indonesia, Singapore, and Malaysia. With regard to belief systems, the two main groups of Indians that have settled in Thailand can be differentiated into Hindus and Sikhs. The majority of these are Hindus. 
Archaeologists have discovered that it was during the era of Ashoka the Great that much of Indian culture was brought into Thailand by migrants; evidence for this includes the erection of several statues at the site of Phra Pathom in Nakhon Pathom and the site of Phing Tuk. The statues there have stood since the 3rd or 4th century A.D. (Cœdès 1968 17-18). Great conflict within India after the reign of King Rama $V$ resulted in mass migration to Thailand.

Just over a century ago, the Sikh migration began. In 1885, two groups of Sikhs-the Khalsa and the Namdhari-migrated to Sukhumvit Road and Ban Khaek, Lampang, and Phitsanulok. Pongsapit (1991) stated that 91 Sikhs moved to Thailand at this time. Now, there are between 30,000 and 40,000 Sikh Indian Thais in the city of Bangkok, most of them having settled in Pahurat, Thaphra, Ban Khaek, Sukhumvit and Klongton.

From the perspective of the Thai people, most Hindus and Sikhs are seen as foreigners even though they have been granted legal citizenship as Thais. This is due to the fact that these peoples still adhere to their own native customs and traditions and still speak their native languages. Furthermore Thai Indians do not intermarry because of the great differences between the two cultures. One way for them to maintain their ethnic identity is by adhering to their traditional naming conventions, usually abstaining from the use of Thai names, except in certain circumstances.

Traditionally in India, names were based on location, religion, caste, and profession and were composed of a phrase, single unit-word, or word-division. According to Kaushik (2000), the probability of occurrence of the last name does not impact the reliable distribution in all terminology places. In many cases, the first part of a name will refer to the place of one's home, and the last part of a name will refer to caste or some other reference.

Previously there have been few studies about Indian Thai groups, and the research that has been done has tended to be about descriptive and historical features of these groups. This research focuses on Hindu and Sikh Indian Thais due to the fact that they are the largest and oldest groups in Thailand. This is the first study to inquire into the conventions for assigning names and surnames to Indian Thais in terms of ethnolinguistics and the cultural perspectives reflected in the names 


\section{Objective}

The main intent of this research is to examine the linguistic structure of Indian Thai naming conventions. Various linguistic components of the names will be analyzed semantic domains.

\section{Materials and Methods}

This research will follow a standardized procedure involving the following four categories: (1) Data Limitation, (2) Data Preparation, (3) Data collection and (4) Data analyses.

\subsection{Data Limitation}

The data limitation for this research is Data for this research approximately 1000 Indian Thais in Bangkok, gathered for analysis of conventions and meanings.

\subsection{Data Preparation}

Important to this study will be the use of journals, articles, textbooks and theses that are pertinent to Indian Thai naming conventions. The theoretical frameworks therein will be important for this study. Foundational to this study will be the collection of data (Indian Thai names) from 1000 informants around Thailand (Bangkok, Pathumthani, Nakhon Pathom, Chonburi, Chiang Mai, Lampun, Lampang, Nakhon Ratchasrima, Phuket, Yala and Trang).

\subsection{Data collection}

For data about naming conventions, sources such as textbooks, dissertations, and journals will be consulted. This will allow the researcher to investigate the structures of 
the naming conventions and the word components themselves, leading to a coherent semantic analysis of social and cultural factors influencing naming conventions.

A sample base of approximately 1000 Indian Thais (500 being Sikh and 500 being Hindu) and their relatives will be interviewed for this research. The sample will consist of Indian Thais whose ancestors migrated to Thailand from India. This data will include focus groups within three to four generations per sample.

\subsection{Data analyses}

Because most Thai names are Sanskritized, the roots of the words/names must be determined. To do this, linguistic features will be analyzed from the data from an ethnolinguistic and semantic perspective. This will be followed by semantic analysis which will involve the categorization of the words based on meaning and a variety of socio-cultural factors. Finally, there will be a discussion of the findings.

Foundational to this study will be the collection of data (Indian Thai names) from 1000 informants around Thailand (Bangkok, Pathumthani, Nakhon Pathom, Chonburi, Chiang Mai, Lampun, Lampang, Nakhon Ratchasrima, Phuket, Yala and Trang).

Because most Thai names are Sanskritized, the roots of the words/names must be determined. To do this, linguistic features will be analyzed from the data from an ethnolinguistic and semantic perspective. This will be followed by semantic analysis which will involve the categorization of the words based on meaning and. Finally, there will be a discussion of the findings.

\section{Hindu Indian Thai naming}

Hindu Indian Thai names are influenced by a variety of social constructs, including the four castes: the brahmanas, or priests, representing purity; the kshatriyas, or warriors, representing courage; the Vaishyas, or businessmen, representing prosperity; and the Shudras, or laborers, representing hard work. The Shudras are often seen as the 
lowest caste in Indian society. Shudras include servants (Kaushik 2000: 13-42). Nowadays, more weight is put in personal preference than in caste.

\subsection{First names}

\subsubsection{Entities semantic domain}

Entities are used for $62 \%$ of Hindu Thai names, as follows:

\subsubsection{Inanimate entities}

a) Natural inanimate entities: Natural phenomena account for $26.8 \%$ of Hindu Indian Thai names (15\% of male names; $11.8 \%$ of female names), as follows:

Celestial-atmospheric entities include the following examples (15.2\% of names are celestial-atmospheric entities; $8.68 \%$ of male names; $6.51 \%$ of female names):

$\begin{array}{llll}\text { (1) Raveena } & \text { (Female, Urdu) } & \text { /ravina/ } & \text { 'beauty of the Sun' } \\ \text { (2) Nabh } & \text { (Male, Sanskrit) } & \text { /nab/ } & \text { 'the sky' } \\ \text { (3) Arundhati } & \text { (Female, Hindi) } & \text { /Parunthati?/ 'the star' } \\ \text { (4) Sabrang } & \text { (Male, Hindi) } & \text { /sapray/ } & \text { 'rainbow' }\end{array}$

Entities related to earth, geography, and names of cities include the following examples $(3 \%$ of names are earth, geography $(1.5 \%$ of male names; $1.5 \%$ of female names):
(5) Pavan
(Male, Hindi)
/pawan/ 'wind, air, breeze'
(6) Hemadri
(Male, Hindi)
/himatri/
'Himalaya mountain'
(7) Swarg
(Male, Hindi)
/sawak/ 'name of city'

Gems make up for $3.2 \%$ of names, include the following examples $(1.92 \%$ of male names; $1.28 \%$ of female names):

$\begin{array}{llll}\text { (8) Himank } & \text { (Male, Hindi) } & \text { /himay/ } & \text { 'diamond' } \\ \text { (9) Neelar } & \text { (Male, Sanskrit) } & \text { /nila/ } & \text { 'emerald' } \\ \text { (10) Panna } & \text { (Female, Hindi) } & \text { /panna/ } & \text { 'gem' }\end{array}$

Names reflecting fire and flame include the following examples [1.2\% of names are fire and flame ( $0.8 \%$ of male names; $0.4 \%$ of female names)]: 

(11) Patag
(Male, Hindi)
/patak/
'fire'
(12) Prajuala
(Female, Sanskrit)
/prattchuala/ 'fire'

Names reflecting water include the following [1.4\% of names are various forms of water $(0.7 \%$ of male names; $0.7 \%$ of female names)]:
(13) Karana
(Male, Hindi)
/karana/
'tide'
(14) Kavana
(Female, Sanskrit)
/kawana/
'tide'

Flora and plant products include the following [ $2.8 \%$ of names are flora and plants

(1.4 \% of male names; $1.4 \%$ of female names as in the following examples)]:

(15) Kalakar

(Male, Hindi)

/kalakan/

'tree'

(16) Kusumakar

(Male, Sanskrit)

/kusumakan/

'the bundle of flower'

(17) Laksha

(Female, Sanskrit)

/laktcha/

'flower, white rose'

(18) Kamal

(Female, Hindi, Punjabi) /kaman/ 'Iotus'

b) Manufactured or constructed inanimate entities: Only $2.8 \%$ (2.45\% of male names; $0.35 \%$ of female names) of Hindu Indian Thais' naming are based on these entities as in the following examples:

Decoration:

(19) Kirit

(Male, Sanskrit)

/ki? rit/

'crown'

(20) Mudrika

(Female, Sanskrit)

/mattharika/ 'ring'

(21) Trishar

(Male, Hindi)

/tritcha/

'necklace'

Lighting and lamps:

(22) Pradeep

(Male, Sanskrit, Hindi)

/prathip/

'lamp'

(23) Deepak

(Male, Hindi)

/dipak/

'lamp, kindle'

Musical instruments:

(24) Bansi

(Male, Hindi, Punjabi) /bansi/

'flute'

Processed substances:

(25) Ikshu

(Male, Sanskrit)

/Piktchu/ 'sugarcane'

(26) Madhur

(Male, Hindi)

/mathura/ 'sweet' 


\subsubsection{Animate entities}

These names make up $32.4 \%$ (27.7\% of male names; $4.7 \%$ of female names) of Hindu Indian Thai names as in the following examples:

a) Animals: $3.14 \%$ of names are related to animals:

$1.57 \%$ of names refer to poultry:

(27) Vihang

(Male, Sanskrit, Hindi) / /wihan/ 'bird'

$1.05 \%$ of names refer to quadrupeds:

(28) Kamboj

(Male, Sanskrit)

/kambot/ 'elephant'

(29) Neshu

(Male, Sanskrit)

/net/ 'lion'

$0.52 \%$ of names refer to body parts of animal:

(30) Muktā

(Female, Sanskrit)

/mukta/ 'pearl'

b) Human beings

$13.6 \%$ of names are human beings (male $12.54 \%$, female $1.05 \%$ ) consist of the following sub-domains:

Generic and distinguished by age and sex:

(31) Bhupen

(32) Kanvar

(33) Riya

Males:

(34) Manish

(35) Hadrik

Offspring:

(36) Haresh Kumar

(37) Jitendra Kumar

(38) Mahesh Kumar

(40) Anusha

(41) Falak Kumar

$\begin{array}{lll}\text { (Male, Bangala) } & \text { /phupen/ } & \text { 'king' } \\ \text { (Male, Punjabi) } & \text { /khanwara/ } & \text { 'young Prince' } \\ \text { (Female, Arabic) } & \text { /riya/ } & \text { 'singer' }\end{array}$

(Male, Sanskrit, Hindi) /manit/

'man who can control thought'

(Male, Urdu)

/hattharika/ 'boy'

$\begin{array}{lll}\text { Male, Hindi) } & \text { /haretkuman/ } & \text { 'The son of Lord Siva' } \\ \text { (Male, Hindi) } & \text { /tcithendrakuman/ 'Son of virtuous father' } \\ \text { Male, Hindi) } & \text { /mahetkuman/ } & \text { 'the son of God' } \\ \text { Male, Sanskrit) } & \text { /?anutcha/ } & \text { 'younger brother' } \\ \text { Male, Urdu) } & \text { /falakkuman/ } & \text { 'son of the sky' }\end{array}$

(Male, Hindi) /tcithendrakuman/ 'Son of virtuous father'

(Male, Hindi) /mahetkuman/ 'the son of God'

(Male, Sanskrit) /?anutcha/ 'younger brother'

(Male, Urdu) /falakkuman/ 'son of the sky' 


\section{Affinals:}
(42) Ira
(Female, Hindi)
/?ira/
'the wife of Manu'
(43) Harini
(Female, Urdu)
/harini/
'deer, darling'

Brothers and sisters:
(44) Pehlaj
(Male, Persian)
/pelat/
'elder brother'
(45) Anusha
(Male, Sanskrit)
/Panutcha/
'younger sister'

Group consists of socio-politics:

(46) Pandey

(Male, Hindi)

/pande/

'a Brahmin sub-caste'

Body, body parts, and body expressions:
(47) Citrākșa
(Male, Hindi)
/ţitraksa/
'expressive eyes'
(48) Nayan
(Male, Sanskrit, Hindi) /najan/
'eyes'

c) Supernatural powers or beings

$15.26 \%$ of supernatural powers or beings are divided into powers or personifications and personal beings:

$4.73 \%$ of names refer to powers or personifications:
(49) Kripa
(Female, Sanskrit)
/kripha/
'merciful'
(50) Rujul
(Male, Sanskrit)
/rutchun/
'honest, faithful'
(51) Riddhi
(Female, Sanskrit)
/ritthi?/
'power'

$10.53 \%$ of names refer to personal beings:
(52) Adhi
(Male, Sanskrit)
/?athi?/
'Name of Lord Ganesha'
(53) Biharikunj
(Male, Sanskrit)
/phihanrikun / 'Name of Lord Krishna'
(54) Gajadhar
(Male, Hindi)
/katchathan/ 'Name of Lord Vishnu'
(55) Jogishwar
(Male, Sanskrit)
/jokhitchawa/ 'The God of yoga'
(56) Kumar Nandana
(Male, Sanskrit)
/kumannandana/ 'son of God'
(57) Abhayā
(Female, Hindi)
/?apheja/ 'Goddess'
(58) Mahesh Kumar
(Male, Hindi)
/mahetkuman/ 'Name of Lord Gan@esa' 


\subsubsection{Abstract semantic domain}

$22.8 \%$ of abstract domain is used for naming which refers to the following name groups:

$8.2 \%$ of names refer to capacity:

(59) Ashvath

(Male, Hindi)

/Pattchawat/ 'Strong like banyan tree'

(60) Daksi

(Female, Sanskrit)

/thaksi)

'expert'

(61) Aiswarya

(Female, Hindi)

/Paytchawa:raya:/'prosperous'

$5.6 \%$ of names refer to number:

(62) Anit

(Male, Hindi)

/Panit/

'small, a little'

(63) Balraj

(Male, Hindi)

/banrat/

'great, big'

$4.8 \%$ of names refer to time:

(64) Arun

(Male, Punjabi)

/Parun/ 'dawn'

(65) Rajni

(Female, Hindi) /

ratçhani/ 'night'

$3.4 \%$ of names refer to good-bad:

(66) Uttam

(Male, Hindi)

/Pattam/ 'good'

(67) Suchir

(Male, Hindi)

/sutphə/ 'Good for long time'

$2.6 \%$ of names refer to attractiveness:

(68) Sanjula

(Female, Hindi)

/sanjula/

'beautiful'

(69) Jahi

(Male, Persian, Hindi) /jahi/

'chic, stylish, handsome'

(70) Kashish

(Female, Persian, Hindi) /katchit/

'charming'

$2.2 \%$ of names refer to status:

(71) Aiswarya

(Female, Hindi)

/Paytchawaraya/ 'prosperous'

(72) Udbal

(Male, Hindi)

/Patbaw/

'famous'

$2 \%$ of names refer to color:

(73) Shweta

(Female, Hindi)

/tchaweta/

'white'

(74) Neela

(Female, Hindi, Urdu) /nila/

'blue'

$1.2 \%$ of names refer to volume which are males:

(75) Suran

(Male, Hindi)

/suran/

'melodious'

$0.2 \%$ of names refer to velocity:

(76) Ranam

(Male, Urdu)

/ranam/

'fast/quick'

$0.2 \%$ of names refer to truth-falsehood:

(77) Tatbir

(Male, Persian)

/thatbə/

'truth' 


\subsubsection{Events semantic domain}

This semantic domain relates to emotions, intellect, and control. Hindu Indian Thai names are based on $15.2 \%$ of this sub-domain.

$16.4 \%$ of names refer to emotions:

$\begin{array}{llll}\text { (78) Khushi } & \text { (Female, Punjabi, Urdu)/khutchi/ } & \text { 'happiness' } \\ \text { (79) Akanksha } & \text { (Female, Hindi) } & \text { /?akantcha/ } & \text { 'desire' } \\ \text { (80) Himal } & \text { (Urdu, Punjabi) } & \text { /himan/ } & \text { 'calm' }\end{array}$

$1.64 \%$ of names refer to intellect:

(81) Jignasa (Female, Sanskrit, Hindi) /tchiknasa/ 'curiosity'

$3.28 \%$ of names refer to control:

$\begin{array}{ll}\text { (82) Amarjeet } & \text { (Male, Punjabi) /?amaratchit/ 'victory' } \\ \text { (83) Shamak } & \text { (Male, Persian, Sanskrit) /tchamak/ 'peace' }\end{array}$

\subsection{Surnames}

The Hindu Indian Thai surnames can be analyzed into 3 semantic domains and several sub domains as follows:

\subsubsection{Entities semantic domain}

This semantic domain accounts for $48.6 \%$ of Hindu Indian Thai Surnames, with the following examples:

\subsubsection{Inanimate entities}

The inanimate (sub-)domain refers to nature, the supernatural, substances, flora/plant entities and manufactured or constructed entities, as follows:

a) Natural inanimate entities: Natural phenomena account for $22.4 \%$ of Hindu Indian Thai surnames, as follows:

$12.92 \%$ of surnames refer to celestial-atmospheric entities:
(84) Lalitaditya
(Sanskrit)
/lalita:thittaya/
'the beautiful sun' 
(85) Kshitij

(Hindi)

/kasidit/

'horizon'

$3.3 \%$ of surnames refer to geography:

(86) Jaldhar

$\begin{array}{ll}\text { (Hindi) } & \text { /ţhanthara/ } \\ \text { (Hindi) } & \text { /sakaradut/ }\end{array}$

'stream, waterway'

(87) Sagardutt

(Hindi)

sakaradut/

'gift of ocean'

$3.2 \%$ of surnames refer to gems:

(88) Kanchan

(Hindi)

/kantchan/

'gold'

(89) Neelam

(Hindi)

/nilam/

'blue sapphire'

$0.9 \%$ of surnames refer to various forms of water:

(90) Mehul

(Persian, Hindi) /mehun/

'rain'

(91) Jaldhar

(Hindi) /jathan/

'stream, waterway'

$2.08 \%$ of surnames refer to flowers:

(92) Kusum

(Hindi)

/kusum/

'flower'

b) Manufactured or constructed inanimate entities: Only $2.2 \%$ of Hindu Indian surnames are based on these entities as in the following examples:

Decoration:

(93) Suvarnamālā

(Sanskrit) /suwanmala/

'gold necklace'

\subsubsection{Animate subdomain}

$24 \%$ of the animate sub-domain is used for Hindu Indian Thai surnames according to the following name groups:

a) Human beings: $7 \%$ of names related to human beings. These consist of $0.4 \%$ of kinship terms:

(94) Nandini

(Hindi)

/nandini/

'Daughter'

(95) Hridyanshu

(Hindi)

/haritjantchu/

'Light of heart'

b) Supernatural powers or beings: Supernatural powers or beings (17\%) consist of the following name groups:

$2.2 \%$ of surnames refer to powers or personifications:

(96) Dhaval

(Sanskrit, Hindi)

/thawan/ 'fair'

(97) Palin

(Hindi)

/palin/

'safeguard' 
$14.8 \%$ of surnames refer to personal beings:
(98) Khagesh
(Hindi)
/khaket/
'God of birds'
(99) Manju
(Hindi)
/mantchu/ 'Lord Siva'

\subsubsection{Abstract semantic domain}

$42.4 \%$ of abstract domain is used for surnames which refer to the following name groups:

$10.8 \%$ of surnames refer to time:

$\begin{array}{llll}\text { (100) Nishita } & \text { (Hindi) } & \text { /nitchita/ 'night ' } \\ \text { (101) Prathysha } & \text { (Hindi) } & \text { /pratya/ } & \text { 'morning' }\end{array}$

$0.2 \%$ of surnames refer to velocity:

(102) Chapal (Hindi) /tcha:pan/ 'fast'

$2.8 \%$ of surnames refer to number:

$\begin{array}{llll}\text { (103) Yakta } & \text { (Hindi) } & \text { /yakta/ } & \text { 'unique' } \\ \text { (104) Nikhil } & \text { (Sanskrit) } & \text { /nikhiw/ } & \text { 'infinite, limitless' }\end{array}$

$3.45 \%$ of surnames refer to status:
(105) Darlat
(Persian, Hindi)
/dalat/
'stability'
(106) Dhureen
(Punjabi, Hindi)
/thuri:n/
'achievement'

$8.2 \%$ of surnames refer to religious character:

$\begin{array}{llll}\text { (107) Ashish } & \text { (Hindi) } & \text { /?atchit/ } & \text { 'blessing' } \\ \text { (108) Oni } & \text { (Hindi) } & \text { /?oni/ } & \text { 'born in a holy place' }\end{array}$

$8.6 \%$ of surnames refer to attractiveness:

$\begin{array}{llll}\text { (109) Manjulas } & \text { (Hindi) } & \text { /mantchulat/ } & \text { 'loveable' } \\ \text { (110) Mohit } & \text { (Hindi) } & \text { /mohit/ } & \text { 'charming' } \\ \text { (111) Nikhil } & \text { (Sanskrit) } & \text { /nikhiw/ } & \text { 'perfection' }\end{array}$

$0.2 \%$ of surnames refer to truth-falsehood:

(112) Tatbir

(Persian)

/tatbə/ 'truth'

$0.2 \%$ of surnames refer to Good-bad:

(113) Sheil (Hindi) /tchiw/ 'good conduct'

$7.4 \%$ of surnames refer to capacity:
(114) Sonya
(Punjabi, Hindi)
/sonya/
'wisdom, clever' 


\subsubsection{Events semantic domain}

$8.8 \%$ of events are used as surnames relate to physiological entities; emotions; intellect, control and movement as in the following examples:

$0.4 \%$ of surnames refer to physiological entities:

(116) Janam (Hindi)

$$
\text { /ţanam/ 'birth' }
$$

$5.75 \%$ of surnames refer to emotions:

(117) Kanth

(118) Parmanand /kan/

/paramanan/ 'superlative joy'

$2.46 \%$ of surnames refer to intellectual:

(119) Tatva (Hindi)

/tatwa/ 'Fundamental idea'

$2.46 \%$ of surnames refer to control: (Punjabi)

$$
\text { /bantcit/ }
$$
'winning power'

(121) Jishnu (Hindi) /tchitsanu/ 'victorious'

$0.4 \%$ of surnames refer to movement: (122) Pretvan (Hindi) /pretwan/ 'moving along'

\section{Sikh Indian Thai naming}

Cole \& Sambhi (1978: 43-97) explained that in the Naming Ceremony of Sikhism, a hymn from the Granth (Sikhism's central text) is chosen at random. The first letter of the hymn, any letter of the alphabet, is chosen as the initial of the child's name. After this, the congregation is asked to suggest a suitable name beginning with that letter. The Sikh Indian Thais' naming can be divided into first names and surnames:

\subsection{First names}

Sikh Indian Thai first names can be analyzed into three semantic domains (Abstract, Entities, and Events). 


\subsubsection{Abstract semantic domain}

$52.68 \%$ of abstract domain is used for the Sikh names which refers to religious character, time, attractiveness, capacity, number, status, good-bad, velocity, and color as in the following detail. Sikhism worships the Guru Granth Sahib and believes in peace.

$39.86 \%$ of names refer to religious character (30.97\% of male; $8.89 \%$ of female):

(123) Darvesh

$\begin{array}{lll}\text { (Male, Hindi) } & \text { /darawet/ 'religious, gentleman' } \\ \text { (Female, Punjabi) } & \text { /thitcha/ } & \text { 'initiation, consecration' }\end{array}$

(124) Diksha

(Female, Punjabi)

thitcha/

$3.21 \%$ of names refer to time ( $2.5 \%$ of male; $0.71 \%$ of female):

(125) Basant

(Female, Punjabi) /phasan/ 'spring season'

(126) Chiranjiv

(Male, Sanskir, Hindi) /tchhirantchip/ 'immortal'

$2.81 \%$ of names refer to attractiveness ( $1.405 \%$ of male; $1.405 \%$ of female):

(127) Komal

$$
\text { (Female, Punjabi) }
$$

/koman/

'tender, soft, delicate'

(128) Mohanbir

(Male, Punjabi)

/mo:hanbə:/ 'beauteous, brave'

$2.2 \%$ of names refer to capacity ( $1.65 \%$ of male; $0.99 \%$ of female):

(129) Chathuv

$$
\text { (Female, Punjabi) }
$$

/tcatthuwa/ 'clever'

$1.4 \%$ of names refer to number ( $0.33 \%$ of male; $0.33 \%$ of female):

(130) Asankh

$$
\text { (Male, Punjabi) /Pasan/ 'countless' }
$$

(131) Ekam

(Female, Punjabi) /Pekam/ 'one, united'

$1 \%$ of names refer to status: ( $0.75 \%$ of male; $0.25 \%$ of female)

(132) Anokh

$\begin{array}{lll}\text { (Male, Punjabi) } & \text { /Panok/ } & \text { 'extraordinary' } \\ \text { (Male, Hindi) } & \text { /darawet/ } & \text { 'humble' }\end{array}$

$1 \%$ of names refer to good-bad ( $0.75 \%$ of male; $0.25 \%$ of female):

(134) Adarsh

(Male, Hindi)

/Padat/

'ideal'

(135) Nirmai

(Female, Hindi)

/niramay/

'without flaw'

$0.4 \%$ of names refer to velocity ( $0.4 \%$ of male):

(136) Teja

$$
\text { (Male, Punjabi) /tetcha/ }
$$

'fast, speedy, sharp'

$0.2 \%$ of names refer to color ( $0.2 \%$ of female):

(137) Basant (Female, Punjabi) /phasan/ 'yellow'

$0.6 \%$ of names refer to age: ( $0.2 \%$ of only female):

(138) Yuvleen (Male, Punjabi) Iyuwalin/ 'absorbed in youthfulness' 


\subsubsection{Entities semantic domain}

42.32\% of entities domain are used for Sikh names, including animate entities (animal, human beings and supernatural powers or beings) and inanimate entities (natural and manufactured or constructed entities).

\subsubsection{Animate entities}

Animate entities sub-domain consists of animals, human beings and supernatural as follows:

a) Animals: $1 \%$ of names are Animals, as follows:

$\begin{array}{llll}\text { (139) Arjun } & \text { (Male, Hindi) } & \text { /?arajun/ } & \text { 'peacock' } \\ \text { (140) Variam } & \text { (Male, Punjabi) } & \text { /wari?am/ } & \text { 'lion' }\end{array}$

b) Human beings: $2.6 \%$ of names are human beings $(2.2 \%$ of male; $0.4 \%$ of female), as follows:

Generic and distinctions by age and sex:

$\begin{array}{llll}\text { (141) Hamin } & \text { (Female, Urdu) } & \text { /hamin/ } & \text { 'woman' } \\ \text { (142) Nina } & \text { (Female, European) } & \text { /nina/ } & \text { 'little girl' }\end{array}$

Group consists of sociopolitical:

$\begin{array}{llll}\text { (143) Fauja } & \text { (Male, Punjabi) } & \text { /faoja/ } & \text { 'army, general' } \\ \text { (144) Meeta } & \text { (Male, Punjabi) } & / \mathrm{mita} / & \text { 'friend' }\end{array}$

Body, body parts, and body products:

$\begin{array}{lll}\text { (145) Mukhlapa } & \text { (Female, Punjabi) } & \text { /mukkhalapha/'face' } \\ \text { (146) Netter } & \text { (Male, Punjabi) } & \text { /net/ }\end{array}$

c) Supernatural powers or beings: $20.3 \%$ of names are related to supernatural powers or beings, as follows:

Powers or personifications:
(147) Taan
(Male, Punjabi)
/ta?an/
'power'
(148) Wafa
(Male, Urdu)
/wafa/
'faithful' 
Personal beings:
(149) Aditya
(Male, Sanskrit, Hindi)/Pathittaya/
'sun, lord Surya'
(150) Arvindera
(Male, Punjabi)
/Parawindəra/
'lord of Horses, lord'

\subsubsection{Inanimate entities}

a) Natural inanimate entities: Natural phenomena account for $11.42 \%$ of Sikh Indian Thais names, as follows:

$6 \%$ of names refer to celestial-atmospheric entities:

$\begin{array}{llll}\text { (151) Dhoop } & \text { (Male, Punjabi) } & \text { /thup/ } & \text { 'at the edge of sunshine' } \\ \text { (152) Divjot } & \text { (Female, Punjabi) } & \text { /thipjot/ } & \text { 'divine light' }\end{array}$

$2.1 \%$ of names refer to entities related to earth, geography:

$\begin{array}{llll}\text { (153) Deenaagal } & \text { (Male, Punjabi) } & \text { /dinakan/ } & \text { 'valley' } \\ \text { (154) Gulzar } & \text { (Male, Urdu) } & \text { /kunsa/ } & \text { 'garden' }\end{array}$

$0.52 \%$ of names refer to gems:

(155) Kanchan (Female, Hindi) /kantchan/ 'gold'

$2 \%$ of names refer to fire and flame:

(156) Jyoti

(Male, Sanskrit, Hindi) /tchayoti?/ 'flame'

(157) Jujhar

(Male, Punjabi) /tchuthan/ 'flame'

$0.8 \%$ of names refer to flora and plant products:

(158) Harzadan (Male, Punjabi) /hasadan/ 'flower'

(159) Kinshuk (Male, Punjabi) /kintchuk/ 'flower'

b) Manufactured or constructed inanimate entities: Only $2.2 \%$ of Sikh Indian Thais' naming are based on these entities as in the following examples:

$1.8 \%$ of names refer to offense weapons:

(160) Talwar (Male, Urdu) /tanwan/ 'sword or dagger'

$0.4 \%$ of names refer to decoration:

(161) Deenaagal (Male, Punjabi) /dinakan/ 'decoration'

$1.96 \%$ of names refer to lighting and lamp stands:

(162) Deepak (Male, Male, Hindi) /dipak/ 'lamp' 


\subsubsection{Events semantic domain}

Events (5\%) are related to physiology, emotion, intellect, control, and transfer. The meaning of events is indicated by the Sikh Indian Thai people's ideal character.

$1 \%$ of names refer to physiology:

(163) Ankur

(Male, Hindi)

/Pankun/ 'sprout, glow'

(164) Deepak

(Male, Sanskrit, Hindi)

/dipak/

'kindle'

$3.2 \%$ of names refer to emotion ( $2 \%$ of males; $0.2 \%$ of females):

(165) Akalsukh

(Male, Punjabi)

/Pakansuk/ 'delight'

(166) Premdeep

(Female, Hindi)

/premthip/ 'The lamp of love'

$1.8 \%$ of names refer to intellect:

(167) Gianparkash (Male, Punjabi)

/ki? anpakat/ 'Light of divine knowledge'

(168) Gianpreet

(Male/Female, Punjabi)

/ki?anprit/

'Lover of divine knowledge'

\subsection{Surnames}

The Sikh Indian Thai surnames can be analyzed into 3 semantic domains and several sub domains as follows:

\subsubsection{Abstract semantic domain}

Abstract domain is used for the Sikhs' surnames (52.57\%) as in the following examples:

$35.11 \%$ of surnames refer to religious character:

(169) Adish

(Punjabi)

/Padit/

'exalted'

(170) Sharan

(Punjabi)

/ţharan/

'taking shelter of the Guru'

$10.04 \%$ of surnames refer to status:
(171) Yash
(Sanskrit, Hindi)
/yat/
'glory'
(172) Yashas
(Sanskrit, Hindi)
/yatchat/
'famous'

$4.41 \%$ of surnames refer to attractiveness:

$\begin{array}{llll}\text { (173) Mehar } & \text { (Punjabi, Hindi) } & \text { /mehan/ } & \text { 'kindness, grace' } \\ \text { (174) Mohit } & \text { (Punjabi) } & \text { /mohit/ } & \text { 'beauty, charming' }\end{array}$


$2.81 \%$ of surnames refer to number:

(175) Pehila (Punjabi) ' /pehila/ first'

$0.2 \%$ of surnames refer to time:
(176) Prabhat
(Hindi)
/praphat/
'dawn'

\subsubsection{Entities semantic domain}

41.34\% of Sikh surnames are from the entities domain, which refers to animate entities (animal, human beings and supernatural powers or beings) and inanimate entities (natural and manufactured or constructed entities).

\subsubsection{Animate entities}

The animate (sub-)domain refers to animals, human beings, and the supernatural, as follows:

a) Supernatural powers or beings: Supernatural powers or beings include the following examples:

$0.2 \%$ of surnames relate to powers or personifications:
(177) Kalyan
(Hindi)
/kala:yan/
'auspicious'

$19.87 \%$ of surnames relate to supernatural beings

$\begin{array}{llll}\text { (178) Akaal } & \text { (Punjabi) } & \text { /Pakan/ } & \text { 'God/Goddess Saraswati' } \\ \text { (179) Mahadev } & \text { (Hindi) } & \text { /mahathep/ } & \text { 'Lord of Siva' } \\ \text { (180) Surina } & \text { (Punjabi) } & \text { /surina/ } & \text { 'Goddess }\end{array}$

b) Human Beings: Human beings $(18.47 \%)$ are represented by social caste, as in the following examples:
(181) Singh
(Punjabi) $\quad / \sin /$
'derive from Kshatriya caste'
(182) Sirinetkul
(Sanskrit)
/sirinetkun/
'derived from Kshatriya caste of Hindu
Varna system from Rajputs of Rajasthan' 


\subsubsection{Inanimate entities}

The inanimate (sub-)domain refers to nature, the supernatural, substances, flora/plant entities and manufactured or constructed entities, as follows:

a) Natural inanimate entities: Natural phenomena account for $2.4 \%$ of Sikh Indian Thai surnames:

$1.6 \%$ of surnames relate to celestial-atmospheric entities:

(183) Mehal

(184) Sudipti

$$
\text { /mehan/ }
$$$$
\text { /suthipti?/ }
$$

'cloud'

'brightness'

$0.2 \%$ of surnames relate to gems:

(185) Hira

$$
\text { (Punjabi) }
$$

/hira/

'diamond'

$0.4 \%$ of surnames relate to flora and plant products:

(186) Vigsai

(Punjabi)

/vigsay/

'blossom'

b) Manufactured or constructed inanimate entities: Manufactured or constructed entities refer to artifacts which can be divided into generic items and offensive weapons. Only $0.6 \%$ of Sikh Indian Thais names are based on these entities as in the following examples:

$0.2 \%$ of surnames are generic:

(187) Nidhi

$$
\text { (Hindi) }
$$

/ni?thi?/

'treasure, wealth'

$0.4 \%$ of surnames relate to offensive weapons:

(188) Tulwa

(Punjabi)

/tunwa/

'sword'

\subsubsection{Events semantic domain}

Events are used for the Sikhs' surnames at $6.09 \%$. The meaning of events, in term of semantic domains, conveys the Sikh Indian Thai people's ideal character.

$3.02 \%$ of surnames relate to emotion:

$\begin{array}{llll}\text { (189) Kaan } & \text { (Punjabi) } & \text { /ka/an/ } & \text { 'wish, desire' } \\ \text { (190) Preet } & \text { (Hindi) } & \text { /prit/ } & \text { 'love' }\end{array}$


$1.78 \%$ of surnames relate to intellect:

(191) Sochai

(Punjabi)

/sotchay/

'by thinking'

$1.29 \%$ of surnames relate to movement:

$\begin{array}{llll}\text { (192) Rijak } & \text { (Sanskrit) } & \text { /ritchak/ } & \text { 'sustenance' } \\ \text { (193) Vigsai } & \text { (Punjabi) } & \text { /vigsay/ } & \text { 'to come into bloom' }\end{array}$

\section{Summary}

Hindu and Sikh names are most common in regards to those names which reflect 'emotions.' Regarding female names, those Hindu and Sikh female names which refer to 'emotions' are most similar, and those referring to 'religious characters' are secondmost similar.

Hindu males and females are named similarly as regards entities; of these, 'natural' and 'animals' sub-domains are highest. The 'emotion' sub-domain the secondhighest.

Sikh males and females are named mostly as 'religious characters'.

From this study, the principal semantic domain is 'religious characters.' For Hindu Indian Thais, values about holy God, spirit and cosmos are important. Most Hindus believe in a few foundational ideas, such as inherent sacredness in nature. Hindus believe that an educated expert, or satguru, is required for an average person to know transcendence. They believe that all life forms are holy, to be loved; therefore they exercise ahimsa, or non-injury.

Sikhism is a monotheistic faith. Sikhism identifies God as being only one. To Sikhs, God is the Designer of the Galaxy, omniscient, timeless and omnipotent. Sikhs do not recognize any other gods.

The results of the data analysis are consistent with the concept of Nida (1975: 174). The result exposed that a semantic sector is comprised of a number of meanings which share semantic elements. 


\section{Popular Indian Thai Naming}

Ferguson (1864) said: "...the etymology of proper names is the only branch then of the subject which can in any sense be called popular, for what men, even of those who care not to enquire the origin of the language they speak, feel some interest or curiosity in knowing the meaning of the names they bear..." (Ferguson apud Rosenthal 2005: 3).

\subsection{Male Hindu Indian Thai names}

\begin{tabular}{|l|l|}
\hline \multicolumn{1}{|c|}{ Name } & \multicolumn{1}{c|}{ Percentage } \\
\hline Arsok 'Without sorrow, happiness, name of emperor' & $18 \%$ \\
\hline Suchir 'Good for a long time' & $12 \%$ \\
\hline Aruna 'Dawn, a god of the Hindus' & $9 \%$ \\
\hline Others & $61 \%$ \\
\hline
\end{tabular}

Table 1. Popular Male Hindu Indian Thai names

Three such names were identified. Arsok is a form of the Indian Ashoka, denoting the importance of happiness. Ashoka, an ancient Indian ruler, urged his kin to practice Buddhist values, he encouraged an air of appreciation for all religions. Ashoka served as an illustration of tolerance for his subjects (Thapar 1973: 51). Suchir (the second name) is the representative of Hinduism which is the "Everlasting way". Everlasting in Hinduism implies those living creatures who will stay alive on Earth until the end of this modern age. The third name, Aruna, is an exemplification of the ruddy gleam of the climbing Sun, which is considered to have otherworldly powers. In Hindu Tradition, Aruna is the charioteer of Surya (the Sun God) and he is additionally the red sky of first light or throughout dawn. The story of his heavenly conception is said in the Astika Parva of Mahabharata (Klostermaier 2007).

\subsection{Female Hindu Indian Thai names}

\begin{tabular}{|l|l|}
\hline \multicolumn{1}{|c|}{ Name } & Percentage \\
\hline Ridhhi 'Power, Hindu God' & $20 \%$ \\
\hline Neela 'A character in Hindu mythology, beautiful' & $11 \%$ \\
\hline
\end{tabular}




\begin{tabular}{|l|l|}
\hline Mukta 'Liberated, pearl' & $7 \%$ \\
\hline Others & $62 \%$ \\
\hline
\end{tabular}

Table 2. Popular Female Hindu Indian Thai names

The name Ridhhi ranks the highest in popularity. Siddhi and Riddhi are the wives of the god Ganesha. Thus, anyone who honors Ganesha are likewise honored by Riddhi and Siddhi and can accomplish everything in their life (Brown 1991: 115-140). The second name, Neela/Nala, is the goddess of Nishadha Kingdom, child of Veerasena and possessed by the God Shani (Doniger 1999). This name is associated with the Hindu female ideal. The third name, Mukta, represents freedom. This is reflected in the fact that many informants migrated from India to start a life in Thailand.

\subsection{Male Sikh Indian Thai names}

\begin{tabular}{|l|l|}
\hline \multicolumn{1}{|c|}{ Name } & \multicolumn{1}{c|}{ Percentage } \\
\hline Harsharan 'One who takes shelter in the Lord' & $40 \%$ \\
\hline Deepak 'Lamp, kindle & $15 \%$ \\
\hline Hukam 'Gods who Command, authority, direction' & $9 \%$ \\
\hline Others & $36 \%$ \\
\hline
\end{tabular}

Table 3. Popular Male Sikh Indian Thai names

Harsharan is the most popular of Male Sikh Indian names. Sikhism recognizes that the spiritual and physical world are entwined (Cole \& Sambhi 1995) and thus seeks to secure the privileges of all individuals. The second name, Deepak, means an oil light. The oil in the Deepak represents the dark part of a human spirit that people have a tendency to sustain, and burning the wick is typical of the atman (self). To accomplish illumination and unite with the preeminent force, one must dispose of materialism (Cole \& Sambhi 1995).

The third name, Hukam, is also associated with Sikhism. In the Sikh Scripture, Guru Nanak, the author of the religion, says: "O Nanak, by the Hukam of God's Command, we travel every which way in resurrection. The entirety of the Universe is liable to the Hukam of the Creator God. Nothing ever happens without the Will of Him." This is acknowledged as one of the essential ideas of Sikhism. 


\begin{tabular}{|l|l|}
\hline \multicolumn{1}{|c|}{ Name } & \multicolumn{1}{c|}{ Percentage } \\
\hline Livsharan 'Absorbed in the Lotus Feet of God' & $35 \%$ \\
\hline Ishwari 'Supreme Goddess' & $18 \%$ \\
\hline Jasdeep 'The lamp radiating God's Glories' & $8 \%$ \\
\hline Others & $39 \%$ \\
\hline
\end{tabular}

Table 4. Popular Female Sikh Indian Thai names

Livsharan is the most popular female Sikh Indian Thai name, followed by Ishwari and Jasdeep. These three names refer to the Sikh Oneness of God.

According to the data, the most popular of male and female Sikh Indian names are associated with Sikhism. The names of Sikhs are consistent in both sexes.

\subsection{The language used in naming}

\begin{tabular}{|l|l|l|}
\hline \multicolumn{1}{|c|}{ Language } & \multicolumn{1}{|c|}{ Hindu's Naming } & \multicolumn{1}{c|}{ Sikh's Naming } \\
\hline Hindi & $73.13 \%$ & $24.39 \%$ \\
\hline Sanskrit & $13.53 \%$ & $2.38 \%$ \\
\hline Punjabi & $1.38 \%$ & $65.36 \%$ \\
\hline Others & $11.95 \%$ & $7.87 \%$ \\
\hline Total & $100 \%$ & $100 \%$ \\
\hline
\end{tabular}

Table 5. Languages used in naming

For Hindu Indian Thai names, Hindi is the most popular for names, followed by Punjabi and then Sanskrit. For Sikhs, Punjabi is the most popular for names, followed by Hindi and then Sanskrit. A different language is sometimes used because of Sikh migration from Uttar Pradesh.

The semantic domains in Indian Thais Naming are composed of 3 domains: the semantic domain of Hindu's names is up to entities, abstract and events. The semantic domain of Hindu's surnames is up to entities, abstract and events. The semantic domain of Sikh's names is up to abstract, entities and event. And the semantic domain of Sikh's surnames is up to abstract, entities and event. There is not relational because the 
relational is the grammatical words. This word is not identifying an individual as content words.

\section{Conclusion}

The results of the data analysis are consistent with the concept of Nida (1975: 174). The result exposed that a semantic sector comprises basically of a number of meanings which share certain semantic elements of each group. The salient of the semantic domains are religious characters. Hindu Indian Thais people named entities (natural and animals) that related to the main concepts of Hinduism. Values about holy God, spirit and cosmos are important to a person's lifestyle. Sikhism respects a monotheistic faith. Sikhism identifies God as the only One. God is the Designer of the Galaxy, courageous, not topic to time or area, and does not take beginning or die. It reflects that both of groups still believe firmly own philosophy of region.

\section{Acknowledgements}

The research presented here was financially supported by Thailand Research Fund (TRF) through the Royal Golden Jubilee Ph.D. Program (Grant No. PHD/0341/2550). I would like to express my gratitude to Assoc. Prof. Sophana Srichampa, my dissertation advisor, for her kind support in my research. In addition, it gives me great pleasure in acknowledging the support and help of Assoc. Prof. Amarjiva Lochan, an expertise in Indian studies, Prof. Suwilai Premsrirat, whose enthusiasm for linguistics conventions had lasting effect. My deep gratitude is also due to the generosity of Assoc. Professor Amon Sangmanee, and Assoc. Prof. Samniang Leurmsai, whose guidance is the key to my success. A very special gratitude needs to be given to my Indian Thai informants who dedicated their valuable time and patience during the data collection. Many thanks must be given to Thailand Research Fund who granted me the Royal Golden Jubilee Scholarship throughout the research process and provided me several noteworthy opportunities. 


\section{References}

BRown, Robert (1991) Ganesh: Studies of an Asian God. Albany: State University of New York.

Cole, O. \& SAMBhI, A. K. (1995) The Sikhs: Their Religious Beliefs and Practices. Sussex (England): Sussex Academic Press.

CaEdès, G. (1968) The Indianized State of Southeast Asia, Kuala Lampur: University of Malaya Press.

DhIRAvegIN, Likhit (2008) Coalition Politics, Political Reform and Democratic Development in Thailand. Bangkok: Thammasat University.

DONIGER, W. (1999) Splitting the Difference: Gender and Myth in Ancient Greece and India. The 1996 Jordan Lectures. Chicago and London: University of London Press and University of Chicago Press.

FERGUSON, R. (1864) Teutonic Name-System: The Teutonic name system applied to the family names of France, England \& Germany. Carlisle: R. \& J. Steel.

JAMES, L. (1975) Notes on ethnosemantics, Honolulu: University of Hawaii.

KAUSHIK, D. K. (2000) Cataloguing of Indic names In AACR-2. New Delhi: Low Price Publications.

Klostermaier, K. (2007) A survey of Hinduism. New York, New York: State University of New York Press.

MPHANDE, L. (2006) Naming and linguistic Africanisms in African American culture. Selected Proceedings of the 35th Annual Conference on African Linguistics: African Languages and Linguistics in Broad Perspectives. Somerville, Mass: Cascadilla Proceedings Project.

NIDA, E. A. (1975) Componential analysis of meaning: an introduction to semantic structure. New York: Mouton Publishers.

Office of the Defence Attache, Royal thal Embassy (2011) Indian Migrants. New Delhi: Government Printing Office.

RosentHAL, D. (2005) Conscious and Mind, England: Clarendon Press.

THAPAR, R. (1973) Asoka and the Decline of the Mauryas, Oxford (England): Oxford University Press. 